\title{
AN ANALYSIS OF LOKO FLOOD DISASTER RESETTLEMENT SCHEME, IN SONG LOCAL GOVERNMENT AREA OF ADAMAWA STATE, NIGERIA.
}

\author{
Ibrahim Saidu \\ Department of Geography, Adamawa State University, Mubi. Nigeria
}

\begin{abstract}
The study examines the socio-economic and political impediments to the planned resettlement scheme for Loko flood disaster victims. A simple random sampling technique was employed to interview 280 household heads by administering to each a questionnaire schedule. Furthermore, purposeful interviews with the respondents, field observations and existing documents formed part of the source of data. Data on the occupation of the respondents, their perception of the scheme, and involvement in decision making about the scheme, as well as funding were collected. The findings of the study show that the scheme has not been successful after 19 years of operation, owing to governments' failure to understand the victims' needs, preferences and hopes; inadequate funding and poor management of the scheme by the government.
\end{abstract}

\section{INTRODUCTION}

In Nigeria, as in many other developing countries, resettlement schemes aimed at alleviating over population, controlling migration or evacuating areas struck by natural and artificial disasters such as flood disaster, insect infestation, construction of large dams, roads, etc. One example of such schemes is the resettlement of a 50,000 multi-ethnic population of Bussa resettlement, as a result of the construction of Kainji Dam in 1964 into a modern town called New Bussa (Faniran, 1972). Another example is that of Maroko people who were relocated by the then colonial government and by the Lagos State Government in 1990. 50,000 inhabitants of Maroko community lost their belongings and traditional homes through the demolition exercise of the state government as a deliberate effort to save the people from flood, disease and death (Cole, 1993).

Another example of forced resettlement scheme is that of the 50,000 Nubians undertaken by the Egyptian Government as an effective instrument for relieving population pressures on the old settled area and from increasing the nation's food production (Tadros, 1977). The situations of Maroko, Bussa and Nubian communities are few examples of millions of people who were forced out of their traditional settlements by governments with the sole aim of improving the social, economic and political conditions of their citizens (Scudder, 1971). In Africa, most of such schemes as the Niger Agricultural project, "the Sabi" valley irrigation project, etc., were all found wanting, involving lack of consideration of the opinions and the involvement of the affected people arising from inadequate planning and execution, and inadequate funding of the project, Silberfein (1976), documented that none of the many resettlement schemes attempted in Africa has been able to duplicate the economic viability of Gezira Resettlement Scheme having commercial orientation based on agricultural land being the critical factor of its success. For instance, Tonga Resettlement Scheme in Zimbabwe (Rhodesa then) is known to have failed owing to 
the beneficiaries' perception of the Scheme as disrupting ties of kindship and friendship (Scudder, (1971), hence their unwillingness to be resettled into a new environment.

The focus of this paper is to examine the problems and prospects of the Loko flood disaster Resettlement scheme. Basically, the paper is to analyse governments' intentions and the people's reactions to the resettlement scheme. The objective of this work is therefore to examine the peoples' perspective on the impediments to the success of the scheme. It is also to analyse and identify the scheme bottle-necks that require considerable attention of the policy makers.

\section{The Study Area}

The study area includes both the flood disaster area developed in linearly in the eastwest direction along the River Loko course at the Yola-Mubi Road axis. It lies between latitude $9^{\circ} 35^{\prime}$ and $9^{\circ} 46^{\prime}$ North of the equator, and Longitude $12^{\circ} 20^{\prime}$ and $13^{0} 30^{\prime}$ East of the Greenwich Meridian (See fig. attached). The inundated area is three and a half kilometers away from the resettlement site which is located to the north of it (see attached fig.). The vegetation, according to Akosim, et al (1999), is that of Northern Guinea Savannah type with the mean annual rainfall of between 900 and $1100 \mathrm{~mm}$ with the rainy season lasting for about $4-5$ months. Adebayo (1999), observed that the annual maximum temperature can reach $40^{\circ} \mathrm{C}$ particularly in April, while minimum temperature can be as low as $18^{\circ} \mathrm{C}$ between December and January. The seasonal variation in relative humidity between J anuary and March is very low $(20-30 \%)$. The main occupation of the people in the area is farming/trading. The area has a mixed ethnic population groups of Hausa settlers in the majority, with Batta, the indigenous group, the Yungur, the Mboi and Fulani in the minority.

\section{Material and Methods}

The methodology consists primarily of three sets of questionnaires administered to 260 household heads randomly chosen from the three wards representing $50 \%$ of the total number of the six wards in the flooded area: Sarkin Hausawa, J auro Hali, J auro Umaru, Loko Arewa, Loko Yamma, and Loko Central wards. One household head was randomly selected and from every second house systematically and interviewed, starting with random sampling in each ward. Twenty (50) households head were also randomly chosen for interview only the forty compound few heads in the resettlement area, and another twenty scheme committee members and officers (Administrators) were randomly chosen and interviewed for the study. In all, 280 respondents were administered a questionnaire copy, each. This sample was drawn from the listed 4,200 inhabitants obtained from the resettlement scheme records for the area. Purposeful interviews with the scheme participants and personal field observations formed part of the data collection strategies. The interviews were however, conducted between the hours of $9.00 \mathrm{am}$ and $5.00 \mathrm{pm}$, with the help of trained research assistants who were fluent both in Hausa (i.e., the Lingua - Franca in the area) and English Languages. Descriptive statistical techniques such as the mean, percentage, and simple tabulations were employed to analyse the data generated. 


\section{RESULTS AND DISCUSSION \\ Occupation of Respondents}

The main occupation of the respondents in the disaster area is farming / trading (80.36\%). Others provide labouring services (5.36\%) as well as fishing (14.29\%) as in Table 1 below:

Table: 1 Primary occupation of Respondents in the Flood Disaster Area

\begin{tabular}{|l|l|l|}
\hline Response & $\begin{array}{l}\text { Number of } \\
\text { Respondents }\end{array}$ & Percentage \\
\hline Farming/Trading & 225 & $80.36 \%$ \\
\hline Labouring & 15 & $5.36 \%$ \\
\hline Fishing & 40 & 14.29 \\
\hline Total & $\mathbf{2 8 0}$ & $\mathbf{1 0 0}$ \\
\hline
\end{tabular}

\section{Willingness to move to the Resettlement Area.}

The scheme has largely been found to be far from being achieved as about $96 \%$ of the respondents interviewed in the flooded area indicated no willingness to resettle at the new site (Tables 2) coupled with the fact that only $25 \%$ of the respondents sampled in the disaster area with the bulk of $75 \%$ of them being migrants from Dabad Tsamiya village in the host Song Local Government Area, and some others from Bauchi State.

The result of the analysis shows that government has failed to understand and respect the target groups' needs, preferences and hopes in relation to development as in Table 2 indicating that $96.15 \%$ of the respondents sampled in the study area are not willing to be resettled but rather prefer to remain in the inundated area which offers favourable farming conditions for both the wet and dry seasons farming in addition to reliable water supply for domestic purposes (Oral interviews with victims and personal observations aided in realizing these findings). Flourishing commercial enterprise steming from the locational advantage of the inundated area along Yola Mubi Road axis coupled with its accessibility to the big population centres of yungur communities, are additional stimulating factors in this regard. The victims' attachment to the endangered area was demonstrated by the Loko River (the flood source) Channel Diversion project initiated in 1993 by the affected community aimed at controlling the flood. On the other hand, all the respondents (100\%) sampled in the scheme area indicated total support for the scheme they appealed for the provision of essential amenities in the resettlement area.

Table 2: Willingness to move to the Resettlement Area

\begin{tabular}{|l|l|l|l|l|}
\hline & Flood Disaster Area & & Resettlement Area \\
\hline Response & No & $\%$ & No & $\%$ \\
\hline Yes & 10 & 3.85 & 20 & 100 \\
\hline No & 250 & 96.15 & 00 & 00 \\
\hline Total & 260 & 100 & 20 & 100 \\
\hline
\end{tabular}

\section{Movement to the Resettlement Area}

The outcome of the analysis reveals that the overwhelming number of people or respondents (92.86\%) in the flooded area have not moved to the resettlement area as against the $7.14 \%$ of them that relocated into it before returning to their previous 
homes due to poor facilities. On the issue of resettlers' return to their original homes from the scheme area, all the respondents (100\%) sampled in the scheme area attributed it to infrastructure failures such as water supply and health (27.86\%); lack of economic incentives to allow for flourishing commercial and agricultural enterprises (32.86\%), poor drainage facilities (28.57\%), and lack of housing (10.71\%) emerging from such a re-ordering of human and physical resources as in Table 3.

Table 3: Reasons for Return to Flood Disaster Area

\begin{tabular}{|l|l|l|}
\hline & No & $\%$ \\
\hline $\begin{array}{l}\text { Lack of water supply and poor } \\
\text { health }\end{array}$ & 78 & 27.86 \\
\hline $\begin{array}{l}\text { Lack of better opportunity for } \\
\text { Agriculture and marketing }\end{array}$ & 92 & 32.86 \\
\hline Poor drainage system & 80 & 28.57 \\
\hline Lack of housing & 30 & 10.71 \\
\hline Total & 280 & 100 \\
\hline
\end{tabular}

\section{Involvement in the Decision making about Resettlement}

Table 4 shows that the overwhelming majority of the respondents (about 77\%) in the flooded area and those in the scheme area (80\%) indicated having had a group consultation but a rushed one, by the scheme administrators shortly after the flood disaster incident. The victims while in unstable mind arising from the disaster effects, initially seemed to be in support of the crash resettlement planned by the state Government but later reviewed their decision to content with the flooded area to retain their past cherished farm holdings. The implication here is that, there has not been active participation of the beneficiaries in the decision making process through the councils and committees, appropriately, as was in the Ghanain case (Tadros, 1977), to facilitate the implementation of the project. This has amounted to ineffective emergency planning built around the beneficiaries' reaction patterns, hence, the resettlement impediments.

Table 4: Consultation during programme Implementation.

\begin{tabular}{|l|l|l|l|l|}
\hline & & \multicolumn{2}{|l|}{ Flood Disaster Area } & Resettlement Area \\
\hline Response & No & $\%$ & No & $\%$ \\
\hline Yes & 20 & 6.92 & 16 & 80 \\
\hline No & 60 & 23.08 & 4 & 20 \\
\hline Total & 260 & 100 & 20 & 100 \\
\hline
\end{tabular}

\section{Respondents' perception of the Resettlement Scheme.}

The outcome of the analysis in Table 5 indicates that majority of the respondents (about $77 \%$ ) in the disaster area as compared to the $80 \%$ who did likewise in the scheme area view the resettlement scheme as disrupting ties of kinship, as the large proportion of $77 \%$ of the victims have remained in the disaster area. Although, people had migrated to other States such as Gombe, Taraba, etc; following the 1990 government attempt to use the threat of punishment to implement the scheme, this however, was resisted by the victims. This result tallies well with that of the Tonga (Scudder, 1971), constituting serious impediments to the scheme under study.

Table 5: Resettlement as disruption to Ties of Kinship and Friendship. 


\begin{tabular}{|l|l|l|l|l|}
\hline Response & \multicolumn{2}{|l|}{ Flood Disaster Area } & \multicolumn{2}{l|}{ Resettlement Area } \\
\hline & No & $\%$ & No & $\%$ \\
\hline Yes & 200 & 76.92 & 5 & 80 \\
\hline No & 60 & 23.08 & 15 & 20 \\
\hline Total & 260 & 100 & 20 & 100 \\
\hline
\end{tabular}

Reference to Table 6, reveals that when asked to comment freely on the entire resettlement programme, respondents, particularly in the flooded area voiced some suspicions that the concerned authorities had allowed political considerations to undermine the goal of concentrating the scheme in the area of high potential (that is the flood disaster area). They believe that, the move was merely a government device to use the flood disaster incident as the basis to get them out of the way so that their fertile farm land could be utilized in a different way. In other words, the respondents (67\%) believe that their resettlement is motivated by government's ambitious agricultural development programme suspected to be well under way in the inundated area. The few respondents in the scheme area on the other hand, expressed a contrary view describing the scheme as a laudable though the scheme authorities were yet to provide adequate necessary modern amenities as functional health, educational, marketing and housing facilities, pipe-borne water and good farmlands in the area.

Table 6: Respondents' view on the Resettlement Scheme.

\begin{tabular}{|c|c|c|c|c|}
\hline & \multirow{2}{*}{$\begin{array}{l}\text { Flood } \\
\text { Area } \\
\text { No }\end{array}$} & Disaster & \multicolumn{2}{|c|}{$\begin{array}{l}\text { Resettlement } \\
\text { Area }\end{array}$} \\
\hline & & $\%$ & No & $\%$ \\
\hline $\begin{array}{lr}\text { For Government } & \text { ambitious } \\
\text { agricultural } & \text { development } \\
\text { programme. } & \end{array}$ & 175 & 67 & 2 & 10 \\
\hline $\begin{array}{l}\text { For Security and Welfare of the } \\
\text { People }\end{array}$ & 25 & 10 & 17 & 85 \\
\hline $\begin{array}{l}\text { For influential individuals device } \\
\text { to form the fertile alluvia }\end{array}$ & 60 & 23 & 1 & 5 \\
\hline Total & 260 & 100 & 20 & 100 \\
\hline
\end{tabular}

\section{(i) Management Impediments}

The results of this survey indicate that majority of the victims of the flood are committed to the flood disaster area and as a way of demonstrating the action, the Loko River channel diversion as a flood control measure on the River Loko was adopted and initiated in 1993 by the affected community on River Loko, being the principal source of the floods. This was executed by the use of heavy machinery such as bulldozers, poclain and such related machinery. The strategy has yielded positive results as the flood incidence has reduced both in frequency and severity since then. This, thus, suggests the need for considering the people's opinion regarding the programme as contended by Ajaegbu (1972) that a planning programme based on the existing patterns of the people's social and economic behaviour is likely to be readily acceptable to the rural population.

Analysis of the results shows that most of the scheme participants have remained unwilling to relocate to the resettlement area. This attitude is a function of poor 
farmlands, unreliable water supply source, lack of market, housing, and drainage facilities in the resettlement area. The primary economic activities in the inundated area are farming, animal rearing, fishing, and trading.

The outcome of the analysis reveals that $60 \%$ of the scheme officials sampled lack previous resettlement experience gained with resettlement from others as was the case with some of the Egyptian and from Ghanaian schemes (Scudder, 1977). Experience relating to the carrying out of the exercise in other related schemes both through the exchange of information and through the implementation of the projects. From the foregoing, it can be seen that the major impediments to the Resettlement scheme include:

\section{(ii) Financial Constraints}

Lack of adequate funds provided from the start is one problem that has been militating against the resettlement scheme for many years (19 years). Sadly, the situation is still very much the same. As this in turn leads to a small over worked staff and reduces the scope of necessary surveys, hence the provision of detailed information which can be used for development following resettlement.

According to the resettlement Scheme record (LFDRS/ 1/ 127), only the total sum of N3.6 million was generated through donations from the host Song Local Government Area Council ( $\$ 30$, 000.00) the Military Government of the then Gongola State, ( $\$ 170,000.00)$ at the inception of the scheme in 1989; while the balance of $\$ 3.4$ million was realized from the appeal fund launched in January 1990, for the resettlement scheme project which was, as reviewed in 2007 by a reconstituted committee on the scheme, estimate at the cost of $\$ 100,000,000.00$. As at the research time, the total sum of $\$ 9,033,353.00$ had been spent on the project. Out of this amount, 23\% ( $\$ 2,080,000.00)$ was spent on site land clearing and environmental impact assessment (E.I.A), while the proportion of $77 \%$ ( $\mathbb{N}$ 8,825,353.00) was spent on identified infrastructures as depicted in Table 7.

\section{Table 7: Expenditures on Provision of Infrastructures in Loko Resettlement Scheme}

\begin{tabular}{|l|l|l|}
\hline Items & Cost in & Source of Funds \\
\hline Site Clearing & $180,000.00$ & Government \\
\hline $\begin{array}{l}\text { Environmental Impact Assessment (E. I. } \\
\text { A) }\end{array}$ & $1,900,000.00$ & Loan \\
\hline 2 Blocks of 16 lock-up shops & $2,343,021.00$ & Government \\
\hline Health Centre & $1,123,100.00$ & Government \\
\hline 2 Blocks of Classrooms & $3,487,232.00$ & Government \\
\hline Total & $9,033,353$ & \\
\hline
\end{tabular}

\section{(iii) Social impediments}

There is the dearth of innovated inputs such as markets, housing, reliable water supply and drainage facilities as well as poor lands both for farms and homes at the resettlement site. However, farmlands in the flooded area are of fertile alluvial soils and are distant (Ranging from $3 \mathrm{~km}-20 \mathrm{~km}$ along the river course) from the resettlement area 


\section{(iv) Technical impediments}

Administrative in experience or inefficiency of the scheme relating to the carrying out of rapid ecological and social surveys, the actual resettlement process, and the planning and implementation of development, following resettlement. This planning should take into consideration the opinions of the people for whom the plans are intended.

\section{Conclusion and Recommendations}

This research was conducted primarily to assess the problems and prospects of the Loko flood disaster resettlement scheme. From the foregoing, it can be concluded that the major impediments to the resettlement scheme include financial constraints, social constraints such as markets, housing, reliable water supply source; drainage facilities and poor lands for both farms and homes at the resettlement site. Other impediments are technical, embracing administrative inexperience of the scheme with particular reference to conducting rapid ecological and social surveys; the actual scheme execution and planning.

In-view of the preceding impediments to the resettlement scheme, the following recommendations are made:

Past management errors of the scheme administrators should be corrected by reviewing the membership of the committees already existing with most of their members lacking the relevant experience for the scheme by the government. People who have had the experience gained with resettlement in other countries both through the exchange of information and the incorporation of those with relevant experience relating to the carrying out of rapid ecological and social surveys, the renovation of the existing marketing, other public and processing facilities be appointed the Committee on the resettlement scheme. In any case, planning should be based on the opinions of the affected participants so as to get them involved actively in the entire process.

The River channel diversion flood control initiative put in place by the affected community be considered and improved upon by the government through the following actions:

Creation of reservoir through construction of Diversion of flood.

This could be achieved by diverting flood water by constructing canals to pass through the natural levees into the adjoining flood plains. These natural levels should be reinforced with concrete walls particularly at where they are likely to collapse.

\section{Improving of Discharge Capacity of the River Reach}

The discharge capacity of the Rivers reach could be enhanced by extending or enlarging the bank of the River within the reach. Alternatively, this could be accomplished by cutting off the River meanders or shortening the channel.

\section{Construction of flood retaining Levels}

These are meant to protect the adjoining flood plain from being flooded. It is usually a strong stable dyke built upon the natural level to reinforce it and increase its height. This construction can help to reduce the storage capacity of the flood plain and the 
conveyance of the River as the water flow of the River covers only the span of the low water bed. The reduction, however, causes higher water levels and flow velocities. Both in frequency and severity since then there is the need to improve on that for better results. This, suggests the need for considering the people's opinion regarding the programme as contended by Ajaegbu (1972) that a planning programme based on the existing patterns of the people's social and economic behavior is likely to be readily acceptable to the rural population.

The flood control measures initiated by the affected Community should be considered and co implemented by dredging the flood source River Loko as a well as building embankments (leaves) or improving the River channel and reafforesting plain or flatlands to check the run-offs that accelerate the flood.

Additionally, good drainage systems such as culverts and gutters should constructed to help in controlling the flood, in the disaster area.

Governments, corporate bodies, public spirited members of society and relevant international agencies should come to the aid of the scheme, financially. The flooded area can be of help in controlling the flood. Governments, corporate bodies, public spirited members of society and relevant international agencies should come to the aid of the scheme, financially.

Credit facilities as well as compensation for the loss of property be granted and paid to the scheme beneficiaries. Furthermore, the poverty alleviation programme designed and put in place by the Federal Government be honestly implemented and well extended to those unfortunate victims. This is to help the affected people of Loko rebuild their lives. 


\section{REFERENCES}

Adebayo. A. A. (1999): Climate: Sunshine, Temperature, Evaporation and Relative Humidity in: Adebayo A. A. and Tukur. A. L. (eds.) Adamawa State in Maps, Yola, Nigeria, Paracelete publishers. P. 20.

Ajaegbu, H. I. (1972): Regional Planning and the Rural Areas in Nigeria in: Barbour, K. M. (ed.) Planning for Nigeria, Ibadan, University Press, pp. 100 - 106.

Akosim, C. et al. (1999): Vegetation and forest Resources in: Adebayo A. A. and Tukur, A.L. (eds.), Adamawa State in Maps, Yola Nigeria paracelete publishers.

Cole, A. S. D. (1973): Thinking about the Future: A Critique of the Limits of Growth, Lodon, Sussex University Press.

Faniran, A. (1972): River Basin as Planning Units in: Barbour, K. M. (ed.), Planning for Nigeria, Ibadan University Press, pp. 128 - 138.

Olawepo, R. A., (2000): Participatory Approach to Rural Resettlement Planning: The Jebba Scheme Experience in Nigeria in: Geo-Studies Forum, International Journal of Environmental and Policy Issues, A publication of Geography Department Unversity of Ilorin.

Ray, H. H. and Bashir, B.A. (1999): Irrigated Agriculture in: Adebayo, A.A. and Tukur A. L. (eds.) Adamawa State in Maps, Yola Nigeria, Paracelete publishers.

Oyedipe, F. P. A (1983): Adjustment to Resttlement: A study of the Resettled peoples in the Kainji Lake Basin, Ibadan, University press Ltd.

Scudder, T. C. (1971): Paper prepared for the symposium on Man-made Lakes and Population Resettlement in Africa, California Institute of Technology, Pasadena, California, U. S. A., pp. 99 - 106

Silberfein, M. (1976): Settlement Schemes and Rural Growth in: Knight, C, G. and Newman, L.J . (eds.) Contemporary Africa, London, prentice Intentional London, pp. $252-253$.

Tadros, H. R. (1977): Problems of Integrated Land Settlement Schemes into Regional National Objectives: The Egyptian Experience in : Mabagunje, A. L. and Francis A. (Eds.), Regional Planning and National Development in Tropical Africa, Ibadan, University Press, pp. 172 - 181. 